\section{Syringe exchange programs in Brazil: preliminary assessment of 45 programs}

\author{
Programas de redução de danos causados \\ pelo uso de drogas no Brasil: \\ caracterização preliminar de 45 programas
}

Elize Massard da Fonseca ${ }^{1}$

José Mendes Ribeiro 2

Neilane Bertoni 1

Francisco I. Bastos 1
1 Centro de Informação Científica e Tecnológica, Fundação Oswaldo Cruz, Rio de Janeiro, Brasil.

2 Escola Nacional de Saúde Pública Sergio Arouca, Fundação Oswaldo Cruz, Rio de Janeiro, Brasil.

Correspondence E. M. Fonseca Departamento de Informações em Saúde Centro de Informação Científica e Tecnológica, Fundação Oswaldo Cruz. Av. Brasil 4365,

Rio de Janeiro, $R J$ 21045-900, Brasil. emassard@cict.fiocruz.br

\section{Abstract}

The present study aims to evaluate the current operation of Brazilian syringe exchange programs (SEP). After consulting national and regional networks of people working in projects/ programs aiming to reduce drug-related harm, we identified 134 potential participant programs. Unfortunately, only 45 SEPs answered a survey, even after repeated attempts. The survey addressed: coverage, funding, procurement of basic supplies, managerial capacity, and the local political environment. Findings were triangulated with in-depth interviews with key informants. The main findings included: satisfactory adherence to the initiatives and adequate documentation, but deficiencies in terms of coverage and monitoring, and uneven procurement of resources. Program personnel work mostly on a provisional basis, despite the efforts of local coordinators. Most programs are funded by the National STDs/AIDS Program. A comprehensive agenda aiming to improve current operations should include: concerted efforts to improve local and regional databanks, incentives/sanctions toward full accountability of initiatives carried by the programs, and a genuine culture of monitoring and evaluation.

Syringe-Exchange Programs; Acquired Immunodeficiency Syndrome; Intravenous Substance Abuse

\section{Introduction}

The use of injection drugs frequently causes harm to the user, to the social network he participates in, and, in some circumstances, to society at large. These harms include risk of overdose 1 , risk of disease transmission (HIV, hepatitis, and other blood-borne pathogens) through sharing potentially contaminated needles and syringes, as well as eventual problems arising from the inappropriate disposal of syringes used in public places 2,3 .

Some studies show that increasing access for injection drug users (IDUs) to sterile needles substantially reduces the transmission of HIV and other blood-borne pathogens, as well as reduces risk behaviors related to the use of injection drugs, such as sharing needles, syringes, and other paraphernalia used in preparing and self-administering injection drugs 4,5 .

With the emergence of AIDS in Western countries at the beginning of the 1980s, and the consequent risk of HIV dissemination, the politics of "harm reduction" gained strength in Europe and Australia 6. The first syringe exchange program (SEP), or be it, the first initiative to systematically exchange used syringes for new (sterile) syringes, was implemented in Holland, in 1984, at the initiative of the drug users themselves, in response to the alarming spread of hepatitis B and C in that population 7 . 
Through these programs, IDUs have access to new/sterile syringes by exchanging used ones, which are thus collected from the community. This has the effect of reducing the circulation of potentially contaminated syringes, as well as providing an opportunity to contact this population, which is otherwise difficult to access, in order to implement, in an integrated way, diverse public health efforts, such as: distribution of condoms, counseling, hepatitis B vaccination, and directing drug users to treatment services 8 . These programs have been implemented throughout the world, contributing to the reduction of infection rates by HIV and other bloodborne infectious agents in countries such as the United Kingdom, Australia, Canada, Spain, Thailand, and some locations in the United States (a country where these initiatives benefit from local and regional, but not federal, funding) 6,8,9,10.

The first attempt to implement such harm reduction strategies in Brazil occurred in the city of Santos, São Paulo, in 1989. However, during that era, the Public Ministry of São Paulo filed civil and criminal actions against the program organizers and the city government of Santos. The legal argument was based on Statute No. 6,368/76. The attorneys interpreted these needle exchange initiatives as a means to "stimulate the consumption of drugs" 11.

The first Brazilian syringe and needle exchange program to be effectively implemented was in Salvador, Bahia, in 1995, stemming from an initiative by the Center for Drug Abuse Studies and Therapy (CETAD), Medical School, Federal University of Bahia, with the support of the state and city governments of Salvador 12 .

Changes in the scope of the National STDs/ AIDS Commission, in 1996, accelerated harm reduction programs in Brazil. The first World Bank loan and resources from the United Nations International Drug Control Program (UNDCP), with the specific objective of preventing the AIDS epidemic among IDUs, would provide fundamental assistance to harm reduction incentives countrywide 13 .

In 1998, Brazil hosted the 9th International Conference on the Reduction of Drug Related Harm. These meetings represented an important moment of articulation of harm reduction professionals, culminating in the creation of two harm reduction associations: the São Paulo Harm Reduction Association (APRENDA), and other association of national scope, the Brazilian Harm Reduction Association (ABORDA) 11. In March of that same year, the first state harm reduction law was passed in São Paulo (State Statute no. 9,758/97). Subsequently, other states and districts approved similar laws 14 .
The AIDS epidemic in Brazil has evolved heterogeneously, as a function of the affected geographical regions and populations. IDUs have an important role in the dynamic of the epidemic in some regions of the country (Southeast, South, coastal Northeast, and Midwest) 15, significantly affecting resident populations not just in metropolitan areas, but also in midsized municipalities 16 .

In diverse Brazilian contexts (with the exception of the southern coast), there has been a decline in HIV infection rates among IDUs in recent years, in addition to a decline in the incidence of HIV among IDUs relative to overall incidence in local and regional populations (reflecting former exposure to HIV) 17. In one study, coordinated by the World Health Organization from 1999/2001, with users recruited from drug use scenes, there was a substantial reduction in HIV infection rates (prevalence and incidence estimates) in Rio de Janeiro, from $25 \% 18$ to, approximately, $8 \%$, parallel to the decline in infection rates of other pathogens, such as Hepatitis B and C 17,19. Similar decline was also observed in two other cities in the study: Santos and Salvador 12,20. The reasons for the decline observed in these three cities include saturation of this population segment, whose size is relatively restricted 21 , transformations in the drug scene 20 , spontaneous change in the behavior of IDUs (safer behaviors), and the role of prevention programs, helping drug users and reinforcing their behavioral change to less risky behaviors 17 .

The drug use scene in Brazil is experiencing substantial changes, and the current drug of choice among the Brazilian IDUs population is cocaine $22,23,24$. In recent years, there has been a progressive increase in cocaine consumption, in the form of powder (snorted or injected) and crack rock (smoked or, eventually, injected) 25 , besides the emergence in the scene of diverse new substances, such as "synthetic drugs" (designer drugs) 26 and the further dissemination of traditional drug consumption, such as solvents 27 .

Preliminary compilations of available information indicate that more than one hundred SEP (in Brazil, called Harm Reduction Programs in recognition that the scope of their activities extends beyond just needle exchange) currently operate within Brazil in different regions, states, and municipalities 3,28. These programs are being implemented by universities, governmental institutions, such as health secretaries, and NGOs 14.

The present study sought to evaluate the effective implementation of harm reduction poli- 
cies related to drug use by NGOs and Brazilian governmental agencies and the daily operation of SEPs in Brazil. Through compilation and analysis of a systematic register of 45 programs in Brazil, the study evaluated both the financing mechanisms of these programs and coverage and structural aspects of the NGOs and governmental agencies that implemented harm reduction activities. In addition, the principal obstacles to the spread and consolidation of these programs were listed and analyzed.

\section{Methodology}

The present study used a cross-sectional survey instrument to collect data about SEPs functioning in Brazil. The survey procedures involved the distribution, systematization, and analysis of data using a self-filled questionnaire, responded to by NGO directors and governmental agencies that developed SEPs. The questionnaires were distributed and responded to during the period from October, 2004 to March, 2005. The target population included HRPs in Brazil in 2004 that conducted syringe exchange during the six months prior to the distribution of the questionnaire and that were identified in a register developed through consultation with the Health Ministry, ABORDA, 11 State Harm Reduction Programs (Acre, Amapá, Bahia, Ceará, Espírito Santo, Minas Gerais, Mato Grosso do Sul, Pernambuco, Paraná, Rio de Janeiro, Rio Grande do Sul), and the State STD/ AIDS Coordination of São Paulo.

The first stage of the study included a systematic search for HRPs operating in the country. It sought to ascertain the actual number of programs, through telephone contact and electronic mail with governmental and nongovernmental institutions. The second phase involved applying the questionnaires, contacting key informants, and analyzing the resulting information.

The SEPs in Brazil were characterized according to the definition of the Health Ministry 14 (p. 12): "Health Reduction Programs comprise a series of activities, developed in the field by especially trained community health agents [called outreach workers], which include needle exchange and distribution, information, education, and communication activities (IEC), counseling, guidance, vaccination against hepatitis, and other activities".

The National STDs/AIDS Program made available a list of the state harm reduction associations, also used by ABORDA. In fact, it was not possible to obtain any systematic list or official registry with national coverage. Given the restricted coverage of the official data, information was solicited (via personal contact, telephone, mail, and e-mail) about SEPs operating in each region, starting with the regional associations.

Information about the study population (the assemblage of SEPs in operation) was, therefore, obtained by integrating and conforming regional lists of 134 programs functioning in the country in 2004. Of these, it was only possible to obtain responses from 45 programs, despite innumerable requests.

The programs were evaluated using information pertaining to five thematic blocks: "program coverage", "financing", "resource control", "organizational capacity", and "political environment". The questions were closed, generating quantitative or categorical responses.

The first thematic block ("program coverage") involved evaluation of the number of beneficiaries (classified as regular, occasional, and abandoned) and of degree of beneficiary adherence (according to interval scales). The second block ("financing") involved sources of funds (from summary of revenue and expenses), sustainability (evaluated as chance of maintaining resources, using interval scales and dichotomous variables) and audit results (using dichotomous variables). The "resource control" block involved the control of syringes and other injection equipment (statistics of distribution and collection). The "organizational capacity” block included: worker affiliations, management autonomy (information furnished according to the distribution of professionals, by type of contract, and management structure, according to number of coordinators, specialists, and field workers), and documentation and registration (using dichotomous variables). Finally, the "political environment" block involved administrators' perceptions of the environment, with respect to support and obstacles perceived/confronted by the programs (interval scale referring to the perception of assistance).

Development of the instrument benefited from items used in a questionnaire formulated by the National STD/AIDS Program, UNDCP, and the Federal University of Minas Gerais, in an empirical study in Brazil: AjUDE-Brasil II Project 3,15 .

A pre-test of the instrument was completed with three programs in September, 2004, leading to necessary adaptations. Dissemination of the questionnaires was done directly (by hand) for organizations in Rio de Janeiro, and by fax and electronic mail (e-mail) for the other states. Additional information was collected by means of telephone contact. 
Systematization, administration, and analysis of the data were completed using the software program SPSS 11.5 (SPSS Inc., Chicago, USA), with basically descriptive aims.

In addition to the information described above, two key informants were interviewed in order to hear their considerations as regional administrators of a number of HIV/AIDS programs. Both were senior managers of programs in the state of São Paulo, with degrees in psychology, and not directly involved in SEP administration. These interviews were conducted using a preliminary interview schedule, although interviewees were allowed the liberty to discuss related topics.

\section{Results}

Of the 134 programs in the general registry, 18 programs were excluded from the start because they did not conform to the criterion of the study's definition of SEPs (having conducted syringe exchange during the six months prior to inclusion in the study) (Figure 1). Effectively,

\section{Figure 1}

Location of syringe-exchange programs (SEP), by municipality and state, data referring to 116 programs*, 2005.

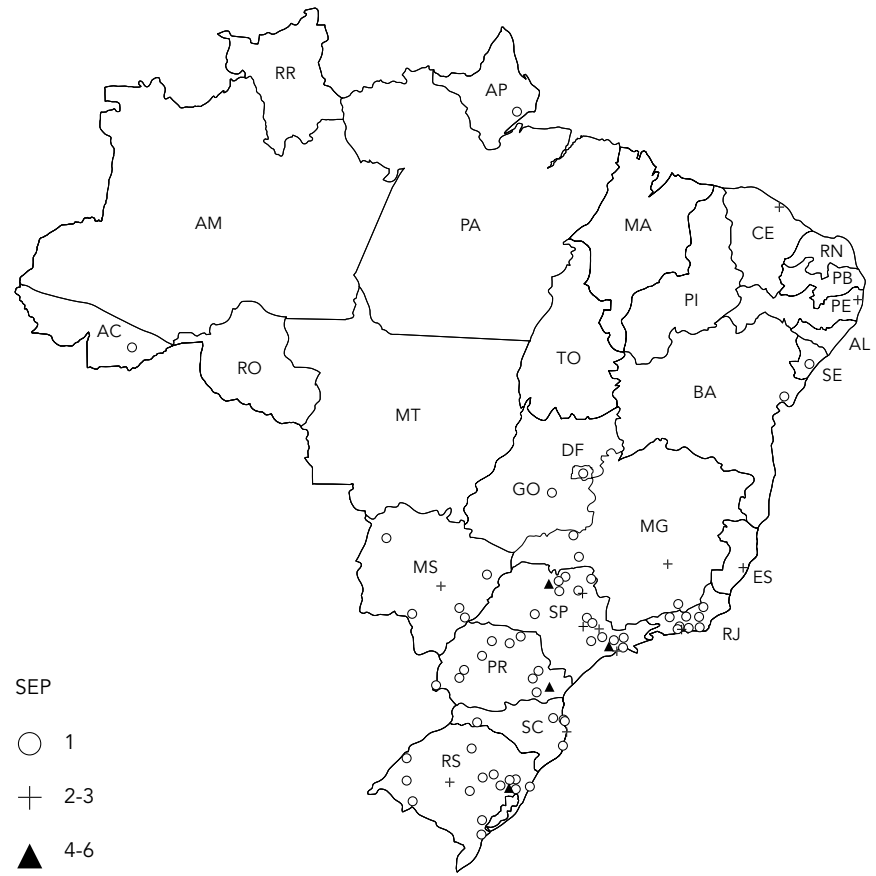

* Excludes 18 programs that did not meet inclusion criteria.
45 programs responded to the survey, despite repeated requests.

The program coverage in relation to the target population was considered poor or average by the majority $(\sim 60 \%)$ of administrators. In weighing coverage deficiency, clientele adherence was considered good or very good for a substantial majority $(\sim 70 \%)$ of administrators. Similarly, interviewees considered the documentation and registry of programs sufficiently adequate (Table 1 ).

The majority (64\%) of programs report verifying adherence of the target population, although no program systematically used valid verification or measurement instruments.

An especially worrying finding is that $20 \%$ of administrators report insufficient syringes and equipment to attend to their activities. Thirteen programs report experiencing interruptions to providing syringes. Despite these discontinuities, the great majority $(90 \%)$ of SEPs report controlling the stock of supplies used by the program.

The 45 SEPs distributed, in total, 126,452 syringes and needles. They collected 90,516 , or $72 \%$ of those distributed. The proportion of syringes and needles distributed/collected varied substantially between programs. A subset of 16 HRPs collected less than $30 \%$ of syringes distributed. Just eight SEPs obtained a satisfactory level of collection of syringes and needles, defined here as $80 \%$ return of distributed material (Figure 2).

As showed in Table 2, interviewees pointed out that the most pertinent assistance afforded SEPs came from federal, state, and municipal organs. In other words, it came from public sources, and predominantly from the federal government. On the other hand, assistance from religious leaders and from the police was very limited, when it existed at all.

The professionals who created these programs (Table 3) served principally in autonomous (55\%) and volunteer (31\%) capacities, or, in other words, had precarious and/or unstable affiliations. More sustainable hiring mechanisms, such as assigned public employees and using contracts managed by the Consolidation of Employment Laws (CLT; Consolidação das Leis Trabalhistas), had a very minor role $(7 \%$ each).

The structural organization of SEPs is basically vertical. Just four SEPs report non-vertical management structures, with staff comprised exclusively of health agents (outreach workers). All the other programs show some degree of centralization, with the presence of, at least, a coordinator. One half of the pro- 
grams report not just a coordinator, but also specialized staff.

Summary financials of SEP operations were requested of directors. The information provided was of variable quality and detail, permitting only a partial synthesis of the results. Solicited of each program were the following: (a) revenue (in reais); (b) sources of this income; (c) expenses, separated in four categories: educational materials, supplies (other than educational materials), equipment, per diem and transportation, and other. This permitted an initial evaluation of program sustainability.

In sum, it is confirmed that the federal government, through the National STDs/AIDS Program, represents the principal technical support, as described above, as the principal (but not exclusive) source of income, whether it be in terms of resource volume or of regularity of financial support. This analysis permitted the identification of programs in vulnerable situations. Four programs counted not only this source of income, but also a second source, whether it be governmental or other. The programs with greatest income diversification were, similarly, those with more elaborate organizational structure and administration. On the other hand, three small programs counted exclusively on income deriving from NGOs and had more fragile structures.

With regard to expenses, four programs reported having expenses greater than their current income, with accumulating debt scenarios. On the other hand, eight programs spent only a fraction of their income, suggesting low implementation capacity.

With regard to "per diem and transportation expenses" - undoubtedly an important aspect of articulating support and exchanging experiences - cases exist where financial equilibrium was compromised by excessive expenses in this area, with apparent harm to end-result activities. Three SEPs show worrying budget performance in this respect, with evident overestimation of expenses in this category (corresponding to more than $30 \%$ of the overall expenses).

\section{Discussion}

This study created a register of NGOs and governmental agencies that developed SEPs in Brazil. The process proved complex and slow, due to the disperse and incomplete nature of the information in all consulted spheres, whether they be federal, state, or municipal, and whether they be public or private. It was
Table 1

Operational characteristics of syringe-exchange programs, according to information provided by their administrators. Brazil, data referring to 45 programs, 2005.

\begin{tabular}{|c|c|c|}
\hline Operational characteristics & $\mathbf{N}$ & $\%$ \\
\hline \multicolumn{3}{|l|}{ Coverage* } \\
\hline Very poor/Poor & 10 & 22.7 \\
\hline Average & 16 & 36.7 \\
\hline Good/Very good & 18 & 40.9 \\
\hline \multicolumn{3}{|l|}{ Adherence* } \\
\hline Very poor/Poor & 0 & 0.0 \\
\hline Average & 14 & 31.8 \\
\hline Good/Very good & 30 & 68.2 \\
\hline \multicolumn{3}{|l|}{ Documentation/registry* } \\
\hline Very poor/Poor & 4 & 8.9 \\
\hline Average & 10 & 22.2 \\
\hline Good/Very good & 30 & 68.9 \\
\hline \multicolumn{3}{|l|}{ Verification of adherence* } \\
\hline Yes & 28 & 63.6 \\
\hline No & 16 & 36.4 \\
\hline \multicolumn{3}{|c|}{ Availability of syringes and equipment } \\
\hline Yes & 36 & 80.0 \\
\hline No & 9 & 20.0 \\
\hline \multicolumn{3}{|l|}{ Stock control } \\
\hline Yes & 41 & 91.1 \\
\hline No & 4 & 8.9 \\
\hline \multicolumn{3}{|l|}{ Continuous availability } \\
\hline Yes & 32 & 71.1 \\
\hline No & 13 & 28.9 \\
\hline \multicolumn{3}{|l|}{ Register of activities } \\
\hline Yes & 45 & 100.0 \\
\hline No & 0 & 0.0 \\
\hline
\end{tabular}

* Incomplete/illegible responses were excluded from the final tabulation.

not even possible to contact 25 of the supposed programs listed by the regional associations, there being serious doubts if these programs are currently operating.

In this respect, the Brazilian programs are not substantially different than their international counterparts, being occupied by difficulties created by conservative local forces, when not in conflict with legal or police proceedings 6 . These programs typically face negative community opinions, which others authors call the NIMBY (non-in-my-backyard) syndrome, the desire to maintaining undesirable populations 
Number of syringe-exchange program by proportion of syringes collected/distributed. Brazil, data referring to 45 programs, 2005.

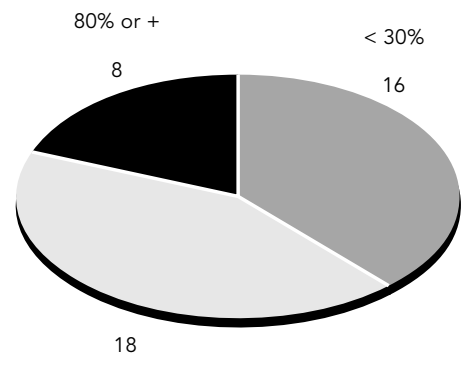

$31-76 \%$

\section{Table 2}

Grades given by administrators on a scale of 1-5, referring to assistance received from different sources. Brazil, data referring to 45 syringe-exchange programs (SEPs), 2005.

\begin{tabular}{lccc}
\hline $\begin{array}{l}\text { Assistance provided } \\
\text { for harm reduction }\end{array}$ & Mean \pm SD & Median & Range \\
\hline Federal organ & $3.9 \pm 1.2$ & 4 & $1-5$ \\
State organ & $3.7 \pm 1.3$ & 4 & $1-5$ \\
Municipal organ & $3.5 \pm 1.2$ & 4 & $1-5$ \\
Religious leadership & $2.1 \pm 1.4$ & 2 & $1-5$ \\
Press & $2.9 \pm 1.6$ & 3 & $1-5$ \\
Police & $2.6 \pm 1.5$ & 3 & $1-5$ \\
Parliamentary members & $2.8 \pm 1.4$ & 3 & $1-5$ \\
\hline
\end{tabular}

* Never answered for the 45 programs in question. Variation of 40-43 SEPs.

separate from residents and recreation or work areas 29. As for the Brazilian literature, resistance to implementing these programs was documented by Andrade et al. 30 .

Our data show that almost $25 \%$ of the programs report deficiencies in coverage, reproducing a deficiency common among these programs at the global level 31. International articles have documented that it would be necessary to increase greatly the coverage of these programs, even in countries with a service structure and model availability of resources, as Canada 31, in order to actually reduce the dissemination of HIV and other blood-borne and sexual infections.
According to program directors, adherence of drug users to the programs studied can be considered satisfactory, although their means of measurement were not rigorous. Good adherence constitutes an indispensable requirement for the functioning of these programs, as long as the discontinuation of activities substantially limits the programs' impact in terms of offering clean syringes and withdrawing used syringes from circulation 32 , as well as the programs' capacity to serve as port of entry for the network of treatment services 33 .

The key informants interviewed, with lengthy experience managing HIV/AIDS programs, considered the documentation and registry of the majority of Brazilian SEPs to be adequate, due to the formal financing requirements, especially with respect to the federal government. On the other hand, the traditional Brazilian culture of "orality" (reiterated by both key informants) would explain the almost complete absence of systematic reports about the day-to-day happenings of local programs. This characteristic of verbal communication is pervasive throughout the Brazilian culture, and was discussed in detail by one of the authors of the present article in relation to Brazilian scientific production regarding HIV/AIDS 34.

According to the key informants, discontinuous flow of supplies essential for the operation of these programs would arise from the lack of organization of these programs, even though they are observed in a positive light as regards the administrative sphere, considering that the majority of programs today have a manager in addition to a technical staff. The precarious affiliations that the majority of professionals tend to have with these programs prevents them from consolidating organizational cultures. Furthermore, constant rotation of these professionals is seen to jeopardize program activities.

A minority of programs manage to optimally combine the distribution and collection of used syringes and needles, as would justify their being designated as programs that $e x$ change and not distribute injection equipment. In is worth repeating at this point that the classic model for evaluating the impact of Needle Exchange Programs, as regards transmission of HIV and other blood-borne pathogens, necessarily involves not just increased access to sterile needles, but also (and foremost) the withdrawal from circulation of contaminated syringes 32 . Furthermore, programs that do not efficiently collect used syringes and needles, or that basically just distribute injection equipment, tend to be seen poorly in their commu- 
nities, especially by conservative groups, which therein find support for their concerns that these programs may stimulate the use of injection drug use and criminality. Although such fears have never been justified (increases in injection drug use and criminality in locations covered by SEPs have never been documented by international evaluations 10,35), the mere supposition that a program could increase injection drug use in a given community tends to alarm those that oppose them 6 .

The interviewees point out that the principal assistance provided to SEPs comes from public federal, state, and municipal institutions, in contrast to the case in the United States, where the use of federal funds for this purpose has been forbidden by successive administrations and where the use of state funds is limited 35 .

The technical and financial assistance of the National STDs/AIDS Program was found to be central to the functioning of these programs, reflecting the involvement by the Health Ministry in these activities, partially financed through an agreement of cooperation with the World Bank. In this regard, there is reason for concern that a subgroup of these programs have debts and financial disequilibrium, which apparently arises from excessive spending on "per diem and transportation," such that their end-result activities (such as syringe and needle exchange, distributing condoms, promoting educational activities, etc.) are jeopardized.

The findings of the present study corroborate and augment the findings of earlier studies 36,37 with restricted coverage, whether in terms of limited resources or of repeated non-cooperation by programs in the evaluation process.

All of the evaluations developed thus far have identified deficiencies to be overcome, including: deficient monitoring of rates of infection by HIV and other pathogens, and also in relation to the possible impact that SEP activities have on risk behaviors.

A recent report by the World Bank 37 (p. i) affirms: "it is difficult to confirm what was effectively achieved by the Brazilian HIVISTD Program and to define the contribution to the issue by the World Bank".

It is worth noting that, in contrast to what occurred in many countries worldwide, these programs were not implemented by direct initiative on the part of target communities, whether by local user associations, as in Holland 7, or by local leaders, as in the first North American programs 38.

In Brazil, these efforts were and are basically vertical, depending on federal incentives and
Table 3

Staff profile and nature of professional afiliations that characterize the syringe-exchange programs. Brazil, data referring to 45 programs, 2005.

\begin{tabular}{lrr}
\hline Variables & N & $\%$ \\
\hline Type of affiliation & 154 & 54.6 \\
$\quad$ Autonomous & 19 & 6.7 \\
Contracts managed by CLT & 19 & 6.7 \\
Ceded public employees & 88 & 31.2 \\
Volunteers & & \\
& & \\
Program management forms & 23 & 50.1 \\
Coordinator, technical staff, outreach workers & 18 & 40.0 \\
Coordinator, outreach workers & 4 & 8.9 \\
Outreach workers only & & \\
\hline
\end{tabular}

resources. Situations of exclusive assistance and financing are worrisome, especially in the case of programs with more fragile structures and those that are not able to diversify their financial sources. These politics reflect, however, the nature of the Brazilian health system and the structure adopted by innumerable other health actions developed in the country.

The Brazilian health system is public and free to all Brazilian citizens. Such structure facilitates the adoption of public policies in different areas. Even so, despite the fact of whatever health actions may be supported by law, the implementation of harm reduction activities did not occur without hesitation, surprise, and objection 6,39 .

The programs here studied demonstrate important and persistent vulnerabilities, in terms of sustainability and coverage. It is imperative that these programs be strengthened, since they deal with marginalized populations, whose actions are regulated by criminal legislation.

The principal challenges to strengthening these initiatives institutionally and programmatically involve improving their infrastructure and logistics, so that these programs do not find themselves overcome by lack of supplies and other constraints to their full operation. It is necessary to increase their connections with civil society, especially with the press, police, and religious and community leaders.

The present study is at once victim and testament to the difficulties encountered by these programs, having had to deal with a high rate of non-response, even though the research instrument was concise and simple. The absence of comprehensive official databanks and resis- 
tance by many administrators represents a challenge to any systematic evaluation. The fragmentary registries and reports impose difficulties to potential evaluators. Thus, the present study is basically descriptive and explanatory. It is hoped, nevertheless, that this analysis stimulates future evaluations, with a representative sample of the whole set of SEPs in the country.

There is no remaining doubt that the difficulties confronting these Brazilian programs do not differ substantially from those dealt with by programs of a similar nature but in different contexts, due to the contradictions between health and drugs policies 40 .

Dealing with a difficult-to-access population that does not trust official authorities, and that, similarly, is not seen positively by those same officials, that is the object o stigmatization and criminalization, makes the implementation and evaluation of these programs a challenge globally.

The principal challenges confronting the politics of harm reduction in Brazil transcend the operation of these programs. Rather, they encompass a conjunction of public actions and relationships with civil society, its opinion leaders, and its legislators. An agenda to address this situation should include: confronting political resistance to implementation and full operation of policies and SEPs; better dialogue and integration with officials/institutions that work with drug use and education, often with distinct if not opposed philosophies; and increased exchange with other vulnerable populations (prison inmates, sex workers, miners).

Recommendations for a (re)formulation of harm reduction policies include: constant watchfulness of rates of infection by HIV and other infections transmitted sexually through blood among IDUs, implementation of actions aimed at improving SEP coverage, and providing resources for the maintenance and empowerment of SEP professionals. To improve their effectiveness, it is important to implement regular monitoring/evaluation, using both the capacities of the SEPs and those of independent auditors. It is fundamental to adopt two important practices to improve transparency and rendering of accounts of these programs: (a) requiring regular and systematic rendering of accounts as pertains to resources received and (b) developing contracting mechanisms as per goals and objectives to structure the relationship between public financiers and the programs.

\section{Resumo}

O presente estudo buscou avaliar a operação cotidiana dos programas de troca de seringas brasileiros (conhecidos, no país, como PRD). Foram identificados 134 PRD, com base na compilação de informações das redes que atuam na área. Por intermédio de uma pesquisa, avaliou-se a cobertura dos programas, o seu financiamento, o controle de insumos, a sua capacidade organizacional e o contexto político local. Os achados, referentes a 45 programas (que, de fato, responderam à pesquisa, após repetidos contatos), foram triangulados com entrevistas com informantes-chave. Foi identificada adesão satisfatória às ações e adequada documentação e registro, mas deficiências de cobertura e monitoramento, além de descontinuidades

quanto aos insumos. Os profissionais que atuam nos programas têm, em sua maioria, inserção profissional precária, embora haja coordenação local, na maior parte dos casos. A maioria dos programas é financiada por verbas provenientes do Programa Nacional de DST/AIDS. Uma agenda abrangente nesse campo deve compreender um aprimoramento dos bancos de dados oficiais referentes aos programas, incentivos/sanções $e$ a exigência de que reportem corretamente as suas ações, além de investimento em monitoração e avaliação.

Programas de Troca de Seringas; Síndrome de Imunodeficiência Adquirida; Uso Indevido de Drogas Parenterais 


\section{Contributors}

E. M. Fonseca planned and conducted the study under the supervision of J. M. Ribeiro and F. I. Bastos. Empirical data were analyzed in collaboration with N. Bertoni. All authors participated in developing and revising the manuscript.

\section{References}

1. Brust J. Acute neurologic complications of drug and alcohol abuse. Neurol Clin 1998; 16:503-19.

2. Drucker E, Lurie P, Wodak A, Alcabes P. Measuring harm reduction: the effects of needle and syringe exchange programs and methadone maintenance on the ecology of HIV. AIDS 1998; 12 Suppl A: S217-30.

3. Caiaffa WT, Bastos FI, Priette FA, Reis AC, Mingoti SA, Gandolfi D, et al. Practices surrounding syringe acquisition and disposal: effects of Syringe Exchange Programmes from different Brazilian regions - the AjUDE-Brasil II Project. Int J Drug Policy 2003; 14:365-71.

4. Des Jarlais DC, Marmor M, Paone D, Titus S, Shi Q, Perlis T, et al. HIV incidence among injecting drug users in New York City syringe-exchange programmes. Lancet 1996; 348:987-91.

5. Bluthenthal RN, Kral AH, Gee L, Erringer EA, Edlin BR. The effect of syringe exchange use on highrisk injection drug users: a cohort study. AIDS 2000; 14:605-11.

6. Bastos FI, Strathdee SA. Evaluating effectiveness of syringe exchange programmes: current issues and future prospects. Soc Sci Med 2000; 51:177182.

7. van den Hoek JA, van Haastrecht HJ, Coutinho RA. Risk reduction among intravenous drug users in Amsterdam under the influence of AIDS. Am J Public Health 1989; 79:1355-7.

8. Dehne K, Grund J, Khodakevich L, Kobyshcha Y. The HIV/AIDS epidemic among drug injectors in Eastern Europe: patterns, trends and determinants. J Drug Issues 1999; 29:729-76.

9. Wood E, Kerr T, Spittal P, Li K, Small W, Tyndall M, et al. The potential public health and community impacts of safer injecting facilities: evidence from a cohort of injection drug users. J Acquir Immune Defic Syndr 2003; 32:2-8.

10. Wodak A, Cooney A. Do Needle Syringe Programs reduce HIV infection among injecting drug users: a comprehensive review of the international evidence. Subst Use Misuse; in press.

\section{Acknowledgments}

The project was partially financed by the Higher Education Improvement Commission (CAPES; Coordenação de Aperfeiçoamento de Pessoal de Nível Superior), with reference to the Masters Thesis in Public Health, Escola Nacional de Saúde Pública Sergio Arouca, Fundação Oswaldo Cruz, 2004.

The authors would like to thank the National STDs/AIDS Program, the Brazilian Harm Reduction Association (ABORDA), the respective state associations, the 45 programs included in the present study, and the key informants, that made this preliminary evaluation possible.

11. Mesquita F. Dar oportunidade de vida ao usuário de drogas injetáveis - polêmica nacional. In: Bastos FI, Mesquita F, Marques LF, organizadores. Troca de seringas, drogas e AIDS. Ciência, debate e saúde pública. Brasília: Ministério da Saúde; 1998. p. 101-12.

12. Ministério da Saúde. A contribuição dos estudos multicêntricos frente à epidemia de HIV/Aids entre UDI no Brasil: 10 anos de pesquisa e redução de danos. Brasília: Ministério da Saúde; 2001.

13. Mesquita F, Doneda D, Gandolfi D, Nemes MI, Andrade T, Bueno R, et al. Brazilian response to the human immunodeficiency virus/acquired immunodeficiency syndrome epidemic among injection drug users. Clin Infect Dis 2003; 37 Suppl 5:S382-5.

14. Coordenação Nacional de DST/AIDS. Manual de redução de danos. Brasília: Ministério da Saúde; 2001.

15. Caiaffa WT, Proietti FA, Carneiro-Proietti AB, Mingoti SA, Doneda D, Gandolfi D. Epidemiological study of injection drug users in Brazil (AjUDEBrasil Project). The dynamics of the human immunodeficiency virus epidemics in the south of Brazil: increasing role of injection drug users. Clin Infect Dis 2003; 37 Suppl 5:S376-81.

16. Szwarcwald CL, Bastos FI, Esteves MAP, Andrade CLT. A disseminação da epidemia da AIDS no Brasil, no período de 1987-1996: uma análise espacial. Cad Saúde Pública 2000; 16 Suppl 1:7-19.

17. Bastos FI, Bongertz V, Teixeira SL, Morgado MG, Hacker MA. Is human immunodeficiency virus/ acquired immunodeficiency syndrome decreasing among Brazilian injection drug users? Recent findings and how to interpret them. Mem Inst Oswaldo Cruz 2005; 100:91-6.

18. Guimarães ML, Bastos FI, Telles PR, Galvão-Castro B, Diaz RS, Bongertz V, et al. Retrovirus infections in a sample of injecting drug users in Rio de Janeiro City, Brazil: prevalence of HIV-1 subtypes, and co-infection with HTLV-I/II. J Clin Virol 2001; 21:143-51. 
19. Hacker M, Friedman S, Telles P, Teixeira S, Bongertz V, Morgado M, et al. The role of "longterm" and "new" injectors in a declining HIV/AIDS epidemic in Rio de Janeiro, Brazil. Subst Use Misuse 2005; 40:99-123.

20. Mesquita F, Kral A, Reingold A, Bueno R, Trigueiros D, Araujo P, et al. Trends of HIV infection among injection drug users in Brazil in the 1990s: the impact of changes in patterns of drug use. J Acquir Immune Defic Syndr 2003; 28:298-302.

21. Walker N, Stover J, Stanecki K, Zaniewski A, Grassly N, Garcia-Calleja J, et al. The workbook approach to making estimates and projecting future scenarios of HIV/AIDS in countries with low level and concentrated epidemics. Sex Transm Infect 2004; 80 Suppl 1:i10-3.

22. Carvalho HB, Mesquita F, Massad E, Bueno RC, Lopes GT, Ruiz MA, et al. HIV and infections of similar transmission patterns in a drug injectors community of Santos, Brazil. J Acquir Immune Defic Syndr Hum Retrovirol 1996; 12:84-92.

23. Telles P, Bastos FI, Guydish J, Inciardi JA, Surrat HL, Pearl M, et al. Risk behavior and HIV seroplevalence among IUDs in Rio de Janeiro, Brazil. AIDS 1997; 11 Suppl 1: S35-42.

24. Caiaffa W. Projeto AjUDE-BRASIL. Avaliação epidemiológica dos usuários de drogas injetáveis dos projetos de redução de danos apoiados pela CN-DST/AIDS. Brasília: Ministério da Saúde; 2001.

25. Santibanez SS, Garfein RS, Swartzendruber A, Kerndt PR, Morse E, Ompad D, et al. Prevalence and correlates of crack-cocaine injection among young injection drug users in the United States, 1997-1999. Drug Alcohol Depend 2005; 77:227-33.

26. Almeida S, Silva M. Characteristics of ecstasy users in Sao Paulo, Brazil. Subst Use Misuse 2005; 40:395-404.

27. Thiesen F, Barros H. Measuring inhalant abuse among homeless youth in southern Brazil. J Psychoactive Drugs 2004; 36:201-5.

28. Bastos FI. Drugs and AIDS: a case study from Brazil. Urban Health and Development Bulletin 2000; 3:30-8.

29. Takahashi LM. The socio-spatial stigmatization of homelessness and HIV/AIDS: toward an explanation of the NIMBY syndrome. Soc Sci Med 1997; 45:903-14.
30. Andrade T, Lurie P, Medina MG, Anderson K, Dourado I. The opening of South America's first Needle Exchange Program and an epidemic of crack use in Salvador, Bahia-Brazil. AIDS Behav 2001; 5:51-64.

31. Remis RS, Bruneau J, Hankins CA. Enough sterile syringes to prevent HIV transmission among injection drug users in Montreal? J Acquir Immune Defic Syndr Hum Retrovirol 1998; 18 Suppl 1:S579.

32. Kaplan EH, Heimer R. A circulation theory of needle exchange. AIDS 1994; 8:567-74.

33. Hagan H, McGough JP, Thiede H, Hopkins S, Duchin J, Alexander ER. Reduced injection frequency and increased entry and retention in drug treatment associated with needle-exchange participation in Seattle drug injectors. J Subst Abuse Treat 2000; 19:247-52.

34. Bastos FI, Coutinho K. Tão longe, tão perto: as pesquisas de AIDS no Brasil (1983-1997). In: Parker R, Galvão J, Bessa MS, organizadores. Saúde, desenvolvimento e política: respostas frente à AIDS no Brasil. São Paulo: Editora 34; 1999. p. 339-95.

35. Lurie P, Drucker E. An opportunity lost: HIV infections associated with lack of a national needleexchange programme in the USA. Lancet 1997; 349:604-8.

36. Centro Latino Americano de Estudos de Violência e Saúde, Fundação Oswaldo Cruz. Avaliação dos projetos de redução de danos (PRD). Relatório final de pesquisa. Rio de Janeiro: Centro Latino Americano de Estudos de Violência e Saúde, Fundação Oswaldo Cruz; 1998.

37. Banco Mundial. Primeiro e segundo projetos de controle de AIDS e DST: relatório de avaliação de desempenho de projeto. Washington DC: Banco Mundial; 2004.

38. Sherman SG, Purchase D. Point defiance: a case study of the United States' first public needle exchange in Tacoma, Washington. Int J Drug Policy 2001; 12:45-57.

39. Strathdee SA, van Ameijden EJ, Mesquita F, Wodak A, Rana S, Vlahov D. Can HIV epidemics among injection drug users be prevented? AIDS 1998; 12 Suppl A:S71-9.

40. Lurie P. When science and politics collide: the federal response to needle-exchange programs. Bull N Y Acad Med 1995; 72:380-96.

Submitted on $24 / J u n / 2005$

Final version resubmitted on 26/Sep/2005

Approved on 27/Sep/2005 